\title{
Effects of Corchorus olitorius L. (Molokhia) Extracts as Functional Cosmetic Materials
}

\author{
Mijung $\mathrm{Kim}^{1}$, Seyeon Park ${ }^{2 *}$ \\ ${ }^{1}$ Department of Health and Cosmetics, Dongduk Women's University, Seoul, Korea \\ ${ }^{2}$ Department of Applied Chemistry, Dongduk Women's University, Seoul, Korea
}

*Corresponding author: Seyeon Park, Department of Applied Chemistry, Dongduk Women's University, 60 Hwarang-ro, 13-gil, Seongbuk-gu, Seoul 02748, Korea

Tel.: +82 29404514

Fax: +82 29404510

Email: sypark21@dongduk.ac.kr

Received October 4, 2016

Revised February 14, 2017

Accepted February 17, 2017

Published March 30, 2017

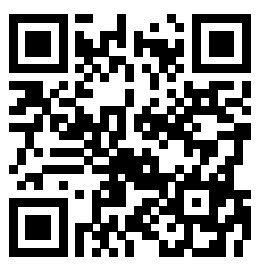

\begin{abstract}
Purpose: This study investigated the possibility of using Corchorus olitorius L. (C. olitorius L., Molokhia) extracts as functional cosmetic materials. Methods: The total extracts of $C$. olitorius $\mathrm{L}$. were fractionated into an oil layer and an aqueous layer and called extract A and B, respectively. Staphylococcus aureus (S. aureus) and Pseudomonas aeruginosa ( $P$. aeruginosa) were used to investigate the antimicrobial effects of extract $A$ and $B$ at concentrations of 0.1 and $0.2 \mathrm{mg} / \mathrm{mL}$. The 3-(4,5-dimethylthiazol-2-yl)-5-(3-carboxymethoxyphenyl)-2-(4-sulfophenyl)-2Htetrazolium, inner salt (MTS) assay was conducted to determine the cytotoxicity of $C$. olitorius L. extract A and B $(10,20$, and $40 \mu \mathrm{g} / \mathrm{mL})$. Anti-oxidant effects were examined using a fluorescent dye, and the effects on collagen synthesis were analyzed by western blotting. Results: Extract A and B showed anti-microbial effects against $S$. aureus and $P$. aeruginosa and were not toxic to the Hs68 or $\mathrm{HaCaT}$ cell lines. The anti-oxidant effects of extract A and B were comparable with that of glutathione, a human anti-oxidant positive control. The C. olitorius $\mathrm{L}$. extracts slightly restored collagen synthesis that decreased after ultraviolet (UV) stimulation. Conclusion: These results suggest that $C$. olitorius $\mathrm{L}$. extracts could become components of functional cosmetics.
\end{abstract}

Keywords: Corchorus olitorius L., Cytotoxicity, Anti-microbial effects, Anti-oxidant effects, Collagen synthesis

\section{Introduction}

생명체는 시간의 흐름에 따라 신체조직과 세포에서 일어나는 생 물학적 변화인 노화의 과정을 거치게 된다. 특히 피부 노화는 피부 의 구조적, 기능적 변화를 말하는데 피부 탄력성과 윤택성의 감소, 피부 색소 침착, 주름 발생 등의 형태로 나타난다(Voegeli et al., 1996). 이러한 노화의 원인으로는 생체 대사과정에서 발생하는 활 성산소(reactive oxygen species, ROS)가 있다(Lee, 2014; Willcox et al., 2004). 활성산소는 장기간 또는 단기간이라도 다량으로 발 생하거나, 혹은 내·외부의 자극 등으로 인하여 발생하면 인체의 방어막을 무너뜨려 단백질 분해, DNA 손상, 나아가 노화와 질병 이라는 문제를 야기한다(Hong, 2009; Lewis, 1993; Marklund \& Marklund, 1974; Re et al., 1999; Willcox et al., 2004; Yu et al., 2005). 이에 대항하여 산화적 손상을 억제하거나 지연시키는 물질
을 항산화 물질이라고 한다. 인체는 자체에 superoxide dismutase, catalase, glutathione reductase, glutathione peroxidase, glutathione-S-transferase 등의 항산화 효소를 가지고 있을 뿐 만 아니라, vitamin $\mathrm{E}$, ascorbate, glutathione 등의 항산화 물질 을 통해서 유해요소로부터 스스로를 보호하기도 한다(Hampton \& Orrenius, 1997; Hong, 2009; Lewis, 1993; Wayner et al., 1987; Yu et al., 2005).

식물체는 항산화 물질과 더불어 미생물을 억제하는 항균 물질 을 가지고 있다(Han et al., 2006). 항균성과 관련된 천연 물질로 는 lactoferrin, lysozyme, chitosan, phenolic, sulfur compound, nisin, polylysine 등이 있다(Cho et al., 2005). 그러나 실생활에서 는 제품의 품질 보존성과 경제성을 위해 합성 보존제가 광범위하 게 사용되고 있다. 합성 보존제의 지속적 사용은 만성 독성, 돌연변 이 유발, 암 발생 등의 문제로 나타나기에 이를 대체할 천연 항균제 


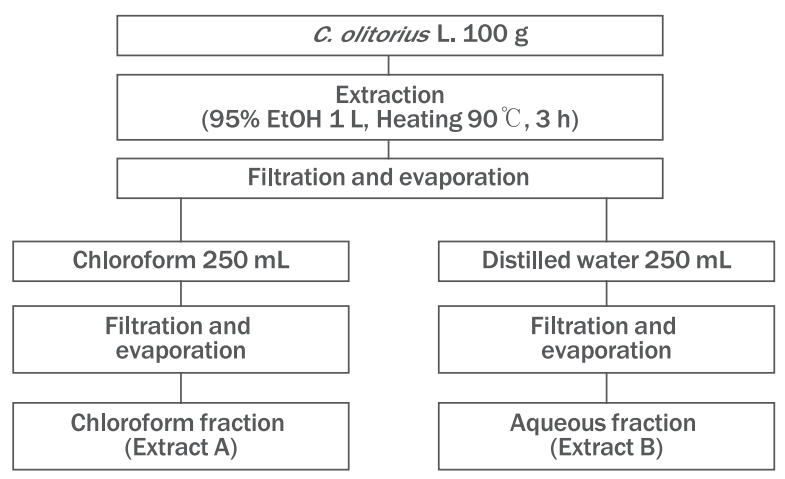

Figure 1. C. olitorius L. extraction method.

Corchorus olitorius L. (C. olitorius L.) was extracted with 1 L 95\% ethanol for $3 \mathrm{~h}$ at $90^{\circ} \mathrm{C}$ on a heating mantle. The ethanol extracts were filtered and concentrated to yield residues. The residues were suspended and partitioned with chloroform and distilled water. The chloroform and distilled water fractions were designated chloroform fraction (extract $A$ ) and aqueous fraction (extract $B$ ), respectively.

에 대한 필요성이 대두되고 있다(Conner \& Beuchat, 1984; Lee et al., 2009; Zaika \& Kissinger, 1981).

최근에 들어서 건강식품에 대한 관심이 아열대 작물로 확장되고 있다. 몰로키아(Molokhia, C. olitorius L.)는 4대 문명의 발상지 중 하나인 이집트의 지중해 연안에서 자생하는 피나무과(Tiliaceae) 1 년초 녹황색 채소이다(Yoshikawa et al., 1997). 몰로키아는 이집트 에서 Jew's mellow 또는 Jew's mallow로 혼용되고 있다. 국내에서 도 일본식 발음인 모로헤이야, 아랍식 발음인 무루키아가 함께 사 용되다가 국립원예특작과학원에서 국제적 학술지에서 통용되는 영 명인 Molokhia를 우리의 발음으로 소개하면서 이를 따르고 있다 (Han \& Yoo, 2009).

몰로키아 잎은 왕가의 수프로서 질병 치료에 사용되었다는 기록 이 있을 만큼 그 영양가치가 주목된다(Jung et al., 2002). 몰로키 아의 영양 구성은 연구에 따라 다소 차이가 있지만 단백질의 함량 이 비교적 높으며 10대 필수 아미노산을 모두 포함하고 있다(ElMahdy \& El-Sebaiy, 1984; Jung et al., 2002). 또한 몰로키아는 카로티노이드인 $\beta$-carotene과 lutein을 포함하고 있으며 페놀성 물질인 caffeoylquinic acid, quercetin도 함유하고 있어서 항산화 효과를 기대할 수 있다(Azuma et al., 1999; Farag et al., 1998). 그 외에도 비타민 B1, B2, C, E 및 칼슘 등의 무기질도 균형 있게 함유하고 있는 채소이다(Oshodi, 1992).

몰로키아의 국내 연구는 식품영양학의 특성에 관한 연구(Jung et al., 2002; Kim et al., 2011; Kim et al., 2015)와 재배와 관련된 연구(Han \& Yoo, 2009; Uhm et al., 2015)에 국한된 채로 미진한 단계이며 화장품의 소재로서의 연구는 아직 진행되지 않고 있다. 따라서 본 연구는 화장품 산업의 발전을 위한 소재 연구의 일환으 로 다양한 생리활성물질을 가지고 있는 몰로키아를 통해 기능성
화장품 소재로서의 가능성을 타진하고자 한다.

\section{Methods}

\section{1. 실험재료 및 추출방법}

본 연구에서 사용한 몰로키아는 이집트에서 2015년 생산된 것으 로서 본 연구자가 두손애약초(Korea)에서 구입하였다. 건조된 몰 로키아 $100 \mathrm{~g}$ 에 $95 \%$ 에탄올 $1 \mathrm{~L}$ 를 가하여 $90^{\circ} \mathrm{C}$ 로 $3 \mathrm{~h}$ 동안 heating mantle (MS-E105; Misung Scientific, Korea)에서 추출하였다. 몰 로키아 에탄올 추출물을 감압 여과한 후 이 용액에 클로로포름과 증류수를 각각 $250 \mathrm{~mL}$ 씩 첨가하고 분획 깔때기를 이용하여 유기 층과 수층으로 분리하였다. 분리된 추출물들을 rotary evaporator (Rotavapor ${ }^{\circledR} \mathrm{R}-114$; BÜCHI Labortechnik AG, Switzerland)로 농 축하여 추출물 $\mathrm{A}$ (몰로키아 유기층)와 추출물 $\mathrm{B}$ (몰로키아 수층)를 얻었다(Figure 1).

\section{2. 시약 및 기기}

본 연구의 실험 중 세포실험에서 사용한 주요 시약으로는 Dulbecco's modified Eagle's medium (DMEM; Welgene, Korea), fetal bovine serum (FBS; Hyclone ${ }^{\mathrm{TM}}$, GE Healthcare Life Sciences, USA), antibiotics (Welgene), phosphate buffered saline (PBS; Hyclone ${ }^{\mathrm{TM}}$ ) 등이 있다. 그리고 MTS assay는 CellTiter $96^{\circledR}$ $\mathrm{AQ}_{\text {ueous }}$ One Solution Cell Proliferation Assay (Promega, USA)을 사용하여 진행하였고, 항산화 효과 실험은 2,7'-dichlorofluorescin diacetate (DCFDA) Cellular Reactive Oxygen Species (ROS) Detection Assay Kit (Abcam, UK), glutathione (Sigma-Aldrich, USA) 등을 사용하여 진행하였다.

Western blotting에는 sodium dodecyl sulfate (SDS; SigmaAldrich), N,N'-methylene-bis-acrylamide (Acrylamide; BioRad Laboratories, USA), nitrocellulose membrane (Thermo Fisher Scientific, USA), skim milk (BD Biosciences, USA), trisbuffered saline/0.5\% tween-20 (TBST; Tech \& Innovation, Korea), 1, 2차 antibody (Santa Cruz Biotechnology, USA), enhanced chemiluminescence (ECL; Invitrogen ${ }^{\mathrm{TM}}$, Thermo Fisher Scientific)가 사용되었다. 그 외에 dimethyl sulfoxide (DMSO; Sigma-Aldrich), ethanol (Sigma-Aldrich), chloroform (Sigma-Aldrich) 등이 사용되었다. 항균 효과 측정 실험에 사용 한 주요 시약은 yeast extract (Duchefa Biochemie, Netherlands), tryptone (BD Biosciences), sodium chloride (NaCl; SigmaAldrich)이다.

주요 기기로는 centrifuge (Union 32R; Hanil Scientific, Korea), $\mathrm{CO}_{2}$ incubator (MCO-175; SANYO Electric, Japan), shaking incubator (VS-8480SF; Vision Scientific, Korea), UV illuminator 
(UV-1000; BoTeck, Korea), microplate reader (Synergy HT; BioTek Instruments, USA), shaker (BF-350SK; BioFree, Korea), heating block (HB-R48; DAIHAN Scientific, Korea), autoradiography cassettes (hypercassette ${ }^{\mathrm{TM}}$; Amersham ${ }^{\mathrm{TM}}$, GE Healthcare Life Sciences)가 사용되었다. 콜라겐 합성 효과의 정 량분석은 Image J program (National Institute of Health, USA) 을 이용하여 수행되었다.

\section{3. 균주와 세포 배양}

본 연구에서 항균 효과를 알아보기 위해서 그람 양성균인 포 도상구균(S. aureus) (KCTC 1927; Korean Collection for Type Cultures, Korea)과 그람 음성균인 녹농균(P. aeruginosa) (KCTC 2004; Korean Collection for Type Cultures)이 사용되었다. 균 주의 배양 배지는 Luria-Bertani (LB)배지(1 L 기준; tryptone $10 \mathrm{~g}$, yeast extract $5 \mathrm{~g}, \mathrm{NaCl} 10 \mathrm{~g}$, 증류수 $950 \mathrm{~g}$ )를 사용하였고 shaking incubator를 이용하여 $37^{\circ} \mathrm{C}, 200 \mathrm{rpm}$ 에서 균주를 배양하 였다.

항산화와 콜라겐 합성 효과를 알아보기 위해서 HaCaT cell (각질 형성세포주, keratinocyte)과 Hs68 cell (섬유아세포주, fibroblast) 을 사용하였다. 이 세포들은 한국세포주은행(Koeran Cell Line Bank, Korea)에서 분양 받았으며 $10 \% \mathrm{FBS}$ 와 $1 \%$ antibiotics를 첨 가한 $\mathrm{DMEM}$ 배지를 이용하여 $37^{\circ} \mathrm{C}, 5 \% \mathrm{CO}_{2}$ 조건의 incubator에서 배양하였다.

\section{4. 몰로키아 추출물의 항균 효과 측정}

시험관에 $\mathrm{LB}$ 배지를 $5 \mathrm{~mL}$ 씩 나누어 넣고 멸균 처리한 후에 대조 군에는 $\mathrm{LB}$ 배지를 첨가하고 $\mathrm{DMSO}$ 용매 대조군에는 $2 \% \mathrm{DMSO}$ 로 처리한 후 포도상구균과 녹농균을 각각 접종하였다. 본 실험에서 $\mathrm{DMSO}$ 용매 대조군은 균주에 추출물 자체의 독성 외에 용매로 사 용된 $\mathrm{DMSO}$ 가 독성으로 작용하는지를 살펴보기 위한 것이며 추출 물 최고 농도에 준하여 처리하였다. 실험에서 균주에 대한 대조군 과 $\mathrm{DMSO}$ 용매 대조군의 차이가 보이지 않아 $\mathrm{DMSO}$ 용매 대조군 을 대조군으로 정하고 진행하였다.

실험군은 $\mathrm{LB}$ 배지 시험관에 몰로키아 추출물들을 $0.1 \mathrm{mg} / \mathrm{mL}$, $0.2 \mathrm{mg} / \mathrm{mL}$ 의 농도로 처리하고 포도상구균과 녹농균을 각각 접 종하였다. 접종이 완료된 시험관 내의 균과 추출물의 활성을 위 해 shaking incubator에서 밤새 배양하였다. 시험관 내의 현탁액 이 균일한 상태에서 $100 \mu \mathrm{L}$ 씩 96-well plate에 담아 microplate reader를 이용하여 $600 \mathrm{~nm}$ 에서 흡광도를 측정하여 항균 효과 값 을 구하였다.

\section{5. 몰로키아 추출물의 MTS assay}

96-well plate에 HaCaT cell과 Hs68 cell를 각각 $1.5 \times 10^{4}$ cells/well, $5.0 \times 10^{3}$ cells/well로 분주하여 $37^{\circ} \mathrm{C}, 5 \% \mathrm{CO}_{2}$ 조건의 incubator에서 배양하였다. 배양된 세포에 몰로키아 추출물들을 각 각 $10 \mu \mathrm{g} / \mathrm{mL}, 20 \mu \mathrm{g} / \mathrm{mL}, 40 \mu \mathrm{g} / \mathrm{mL}$ 의 농도로 처리하여 $24 \mathrm{~h}$ 동 안 incubator에서 추가 배양하였다. 배양 후 각 well에 MTS 시약 을 $20 \mu \mathrm{L}$ 씩 넣고 $3 \mathrm{~h}$ 후에 formazan이 형성되면 $\mathrm{DMSO}$ 로 녹인 후 microplate reader를 이용하여 $495 \mathrm{~nm}$ 에서 흡광도를 측정하였다. Cell viability는 몰로키아 추출물 첨가군과 $\mathrm{DMSO}$ 용매 대조군의 흡광도 차이를 통하여 백분율로 나타내었다.

Cell viability $(\%)=(\mathrm{A} / \mathrm{B}) \times 100 \%$

$\mathrm{A}$ : 추출물 첨가군의 흡광도

$\mathrm{B}$ : 추출물 무첨가된 $\mathrm{DMSO}$ 용매 대조군 흡광도

\section{6. 몰로키아 추출물의 항산화 효과 측정}

96-well plate에 HaCaT cell을 $1.5 \times 10^{4}$ cells/well로 분주한 후 $37^{\circ} \mathrm{C}, 5 \% \mathrm{CO}_{2}$ 조건의 incubator에서 배양하였다. $24 \mathrm{~h}$ 배양된 세 포에 PBS로 2회 세척한 후 phenol red가 없는 PBS에 DCFDA시약 을 $20 \mu \mathrm{M}$ 의 농도로 $45 \mathrm{~min}$ 처리하였다. $\mathrm{PBS}$ 로 2 회 세척하고 50 $\mu \mathrm{M}$ hydrogen peroxide $\left(\mathrm{H}_{2} \mathrm{O}_{2}\right)$ 와 $10 \mu \mathrm{g} / \mathrm{mL}$ 및 $20 \mu \mathrm{g} / \mathrm{mL}$ 의 농도 의 추출물을 $45 \mathrm{~min}$ 동안 처리한 후 microplate reader를 이용하여 $485 / 528 \mathrm{~nm}$ 에서 형광을 측정하였다.

\section{7. 몰로키아 추출물의 콜라겐 합성 효과 측정}

콜라겐 합성 효과는 western blotting을 이용하여 측정하였다. 6-well plate에 Hs68 cell을 $5.0 \times 10^{4}$ cells/well로 분주한 후 $37^{\circ} \mathrm{C}$, $5 \% \mathrm{CO}_{2}$ 조건의 incubator에서 $24 \mathrm{~h}$ 동안 배양하였다. 그 후 $\mathrm{PBS}$ 로 2 회 세척하고 UV illuminator에서 $0.8 \mathrm{~mJ} / \mathrm{cm}^{2} \mathrm{UVA}$ 와 $1.1 \mathrm{~mJ} / \mathrm{cm}^{2}$ $\mathrm{UVB}$ 를 동시에 $100 \mathrm{~s}$ 동안 조사하였다. UV 조사 후 $5 \%$ antibiotics 가 첨가된 serum free DMEM $2 \mathrm{~mL}$ 에 최종농도 $20 \mu \mathrm{g} / \mathrm{mL}$ 의 추 출물을 $20 \mu \mathrm{L}$ 첨가한 배지를 well에 처리하고 $24 \mathrm{~h}$ 배양하였다. 배양된 cell을 PBS로 세척하고 $2 \mathrm{X}$ SDS를 첨가하여 scraper로 끌 어 모아 마이크로 튜브에 담아 heating block에서 $100^{\circ} \mathrm{C}$ 로 $10 \mathrm{~min}$ 동안 끓여준 후 단백질 sample을 얻었다. 준비된 sample을 $10 \%$ SDS-polyacrylamide gel을 이용하여 전기영동한 후 nitrocellulose membrane으로 transfer한 후 5\% skim milk로 blocking하였 다. Glyceraldehyde 3-phosphate dehydrogenase (GAPDH) 와 collagen 1차 antibody를 밤새 반응시키고 2차 antibody를 2 $\mathrm{h}$ 동안 결합시킨 다음 $1 \mathrm{X}$ TBST로 세척한다. Membrane에 ECL detection system을 적용한 후 autoradiography cassettes에서 X ray film에 노출시켜 band를 확인하여 콜라겐 합성 효과를 측정하 였다. 단백질 보정을 위해서 GAPDH antibody를 이용하였다.

\section{8. 통계처리}

본 연구는 모두 3 회 이상 진행하여 나온 표와 그래프의 수치를 각각의 실험 횟수에 대한 평균(mean, $\mathrm{M}$ )과 표준편차(standard 


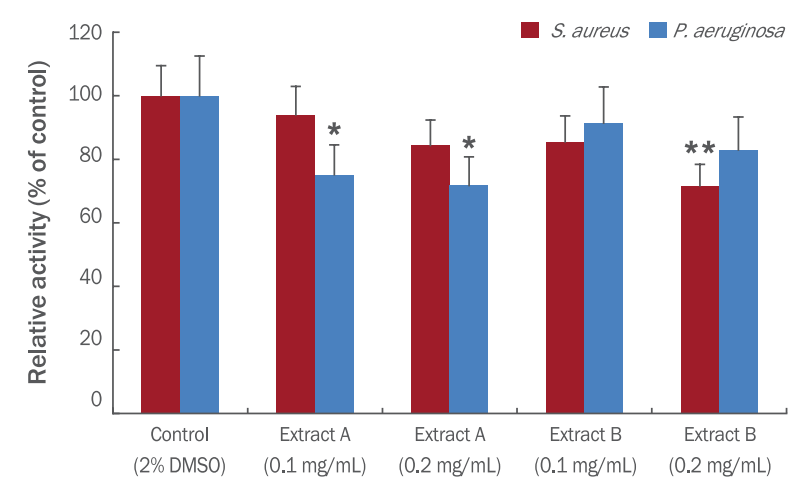

Figure 2. Anti-microbial effects of $C$. olitorius L. extract A and B. Anti-microbial effects of $C$. olitorius $\mathrm{L}$. extracts were investigated by determining bacterial growth using the absorbance value. Staphylococcus aureus (S. aureus) and Pseudomonas aeruginosa ( $P$. aeruginosa) were added to $C$. olitorius $\mathrm{L}$. extract $\mathrm{A}$ and $\mathrm{B}$ at concentrations of 0.1 and $0.2 \mathrm{mg} / \mathrm{mL}$, respectively. Both extracts decreased growth of $S$. aureus and $P$. aeruginosa. Values are mean \pm standard deviation (M \pm S.D.) of three independent experiments $\left({ }^{*} p<0.05,{ }^{* *} p<0.01\right)$. Control, $2 \%$ dimethyl sulfoxide (DMSO) treated group.

deviation, S.D.)로 나타내었다. Sample에 대한 통계적 유의성 분 석은 Student's t-test로 검증하였으며, $p<0.05\left({ }^{*} p<0.05,{ }^{* *} p<0.01\right)$ 인 값을 유의미한 것으로 판정하였다.

\section{Results and Discussion}

\section{1. 몰로키아 추출물의 항균 효과 측정}

몰로키아 추출물 $\mathrm{A}$ 와 $\mathrm{B}$ 의 항균력을 알아보기 위해 여드름 발 생의 주 원인 균으로 알려진 포도상구균(S, aureus)과 녹농균(P. aeruginosa)에 몰로키아 추출물 $\mathrm{A}$ 와 $\mathrm{B}$ 를 $0.1 \mathrm{mg} / \mathrm{mL}, 0.2 \mathrm{mg} / \mathrm{mL}$ 의 농도로 각각 처리하여 항균력을 측정하였다. 포도상구균에 대해 추출물 $\mathrm{A}$ 와 추출물 $\mathrm{B}$ 는 모두 농도의존적으로 항균 효과를 나타내 었다. $0.1 \mathrm{mg} / \mathrm{mL}, 0.2 \mathrm{mg} / \mathrm{mL}$ 의 농도에서 추출물 $\mathrm{A}$ 는 $6 \%, 16 \%$ 의 효과를 나타냈고 추출물 $\mathrm{B}$ 는 $14 \%, 28 \%$ 의 항균력을 보였다. 녹농균 에서도 추출물 $\mathrm{A}$ 와 추출물 $\mathrm{B}$ 의 항균 효과는 농도의존성 경향을 보

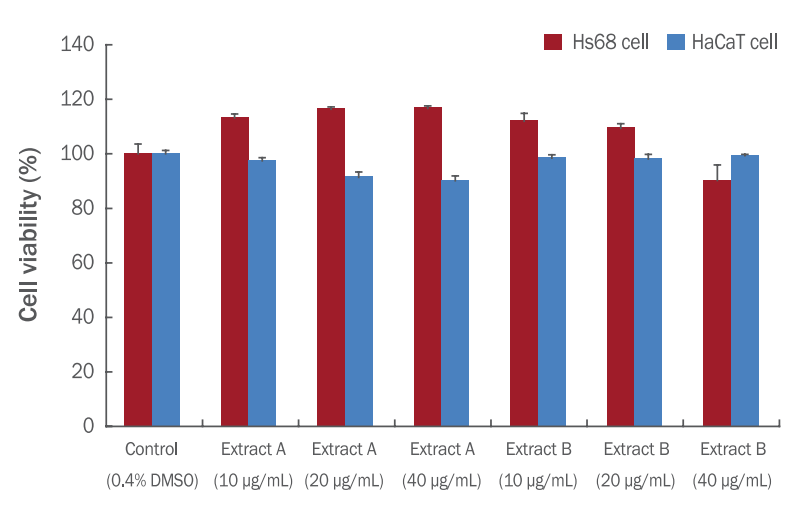

Figure 3. Effects of $C$. olitorius $L$. extract $A$ and $B$ on cell viability.

Cytotoxicity of the $C$. olitorius $\mathrm{L}$. extracts was investigated using the 3-(4,5-dimethylthiazol-2-yl)-5-(3-carboxymethoxyphenyl)-2(4-sulfophenyl)-2H-tetrazolium, inner salt (MTS) assay. Hs68 and $\mathrm{HaCaT}$ cells were treated with $C$. olitorius $\mathrm{L}$. extract $\mathrm{A}$ and $B$ at concentrations of 10,20 , and $40 \mu \mathrm{g} / \mathrm{mL}$. The extracts showed no comparable cytotoxicity. Cell viability is expressed as a percentage of control, and values are $\mathrm{M} \pm \mathrm{S}$.D. of three independent experiments. Control, $2 \%$ dimethyl sulfoxide (DMSO) treated group.

였다. 추출물 $\mathrm{A}$ 에서는 $25 \%, 28 \%$ 의 항균 효과가 나타났고, 추출물 $\mathrm{B}$ 에서는 $9 \%, 17 \%$ 의 결과가 나타났다. 따라서 몰로키아 추출물이 그람 양성균인 포도상구균과 그람 음성균인 녹농균에 대해 항균력 이 있음을 확인할 수 있었다(Figure 2).

\section{2. 몰로키아 추출물의 세포독성 측정}

몰로키아 추출물의 독성에 대해 알아보고자 MTS assay를 진행 하였다. 본 연구에서 사용된 Hs68 cell과 HaCaT cell에 대해 몰로 키아 추출물 $\mathrm{A}$ 와 추출물 $\mathrm{B}$ 를 $10 \mu \mathrm{g} / \mathrm{mL}, 20 \mu \mathrm{g} / \mathrm{mL}, 40 \mu \mathrm{g} / \mathrm{mL}$ 로 처리하여 독성의 정도를 살펴보았다. Hs68 cell에서 추출물의 세포 생존율은 추출물 B의 $40 \mu \mathrm{g} / \mathrm{mL}$ 를 제외하고는 대조군에 비해 높게 나타났으며, $\mathrm{HaCaT}$ cell에서도 추출물 $\mathrm{A}$ 와 추출물 $\mathrm{B}$ 의 독성이 크 지 않은 것으로 나타났다. 이로서 몰로키아 추출물의 항산화 및 콜 라겐 합성 실험을 해당 농도 내에서 진행할 수 있는 것으로 판단되 었다(Figure 3).

Table 1. Quantification of collagen synthesis effects of $\boldsymbol{C}$. olitorius L. extracts

\begin{tabular}{lrrrr}
\hline & Collagen & GAPDH & Collagen/GAPDH & Relative activity (\%) \\
Control & 30626 & 18598 & 1.64672 & 100.00 \\
UV control & 10451 & 19975 & 0.52321 & 31.77 \\
Extract A & 12631 & 15435 & 0.81833 & 49.69 \\
Extract B & 15353 & 15905 & 0.96532 & 58.62 \\
\hline
\end{tabular}

Collagen synthesis effects of $C$. olitorius $\mathrm{L}$. extract $\mathrm{A}$ and $\mathrm{B}$ were quantified using the Image J program. Each value was normalized to GAPDH band intensity. Extract A and B slightly affected collagen synthesis compared with that of a ultraviolet (UV) control. 


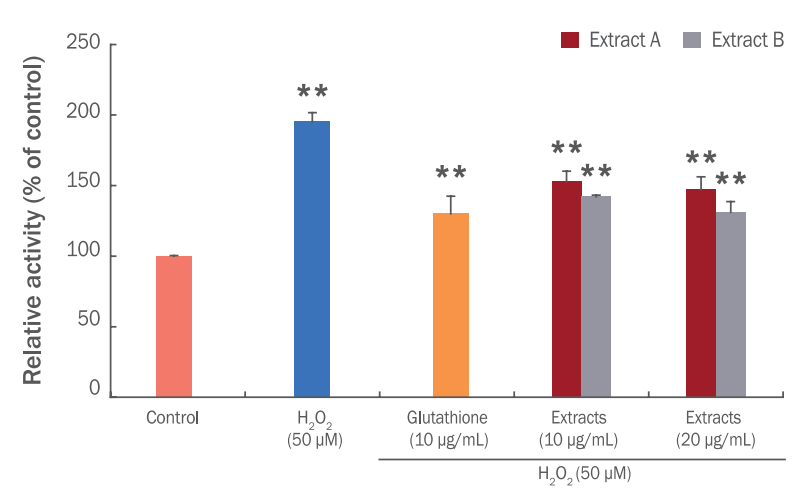

Figure 4. Anti-oxidant effects of $C$. olitorius $L$. extract A and B on HaCaT cells.

After treatment with the reactive oxygen species inducing agent $\mathrm{H}_{2} \mathrm{O}_{2}$, HaCaT cells were treated with $C$. olitorius L. extract $A$ and $\mathrm{B}$ (10 and $20 \mu \mathrm{g} / \mathrm{mL}$ ). Relative activity of the $\mathrm{H}_{2} \mathrm{O}_{2}$-treated group increased 195\% compared to that of the control. C. olitorius $\mathrm{L}$. extract $A$ and $B(10$ and $20 \mu \mathrm{g} / \mathrm{mL}$ ) decreased oxidative stress in $\mathrm{H}_{2} \mathrm{O}_{2}$-treated cells. Values are $\mathrm{M} \pm \mathrm{S}$.D. of three independent experiments $\left({ }^{* *} p<0.01\right)$.

\section{3. 몰로키아 추출물의 항산화 효과 측정}

몰로키아에는 카로티노이드 성분과 페놀성 성분이 풍부한 것으 로 알려져 있어 항산화 효과에 대한 실험을 진행하였다. $\mathrm{HaCaT}$ cell에 DCFDA 시약을 처리한 후 활성산소를 유발시키기 위해 세 포에서 활성산소를 증가시키는 물질인 $\mathrm{H}_{2} \mathrm{O}_{2}$ 를 처리하여 산화스트 레스를 증가시키고 몰로키아 추출물 $\mathrm{A}$ 와 추출물 $\mathrm{B}$ 를 $10 \mu \mathrm{g} / \mathrm{mL}$, $20 \mu \mathrm{g} / \mathrm{mL}$ 씩 각각 처리한 다음 485/528 nm에서 산화스트레스 억 제 정도 즉, 항산화 효과를 측정하였다. 그 결과, 몰로키아 추출물 $\mathrm{A}$ 와 추출물 $\mathrm{B}$ 모두 농도의존적으로 산화스트레스가 감소하였으며 $\left.{ }^{* *} p<0.01\right)$, 특히 양성대조군으로 사용한 glutathione $(10 \mu \mathrm{g} / \mathrm{mL})$ 과 도 유사한 항산화력을 갖고 있다는 것을 확인할 수 있었다(Figure 4).

\section{4. 몰로키아 추출물의 콜라겐 합성 효과 측정}

몰로키아 추출물이 자외선에 의해서 손상된 콜라겐 합성에 효과 가 있는지를 살펴보기 위하여 인간 피부 섬유아세포주(Hs68 cell) 에 자외선을 조사한 후 추출물을 처리하고 western blotting을 진 행하였다. Western blotting 결과에서는 추출물 $\mathrm{A}$ 에 비해 추출물 $\mathrm{B}$ 에서 콜라겐 합성 효과가 조금 더 보이기는 하였으나, 추출물 $\mathrm{A}$ 와 B 모두 유의한 효과는 관찰되지 않았다(Figure 5). 그러나 이를 Image $J$ program을 통해 수치화하여 기준 단백질인 GAPDH양에 대하여 보정한 결과에서는, 추출물의 콜라겐 합성 효과를 조금 더 명확하게 확인할 수 있었다(Table 1).

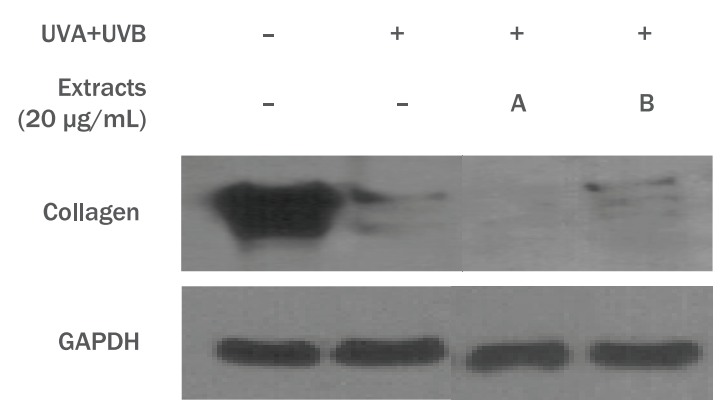

Figure 5. Effects of $C$. olitorius $\mathrm{L}$. extract A and B on collagen synthesis.

Effects of the $C$. olitorius $\mathrm{L}$. extracts on collagen synthesis were measured by western blotting. After UVA $\left(80 \mathrm{~mJ} / \mathrm{cm}^{2}\right)$ and UVB $\left(110 \mathrm{~mJ} / \mathrm{cm}^{2}\right)$ irradiation, Hs68 cells were treated with $20 \mu \mathrm{g} / \mathrm{mL}$ C. olitorius L. extract A and B for $24 \mathrm{~h}$. Cell lysates were separated by sodium dodecyl sulfate-polyacrylamide gel electrophoresis, transferred to a nitrocellulose membrane, and probed with collagen and glyceraldehyde 3-phosphate dehydrogenase (GAPDH) antibodies. Collagen synthesis was higher in extract B than that in extract $A$, but no significant effects were detected by either extract.

\section{Conclusion}

본 연구는 건강식품으로 주목받고 있는 몰로키아의 화장품 신원료 로서 가능성을 타진하기 위해 진행되었다. 몰로키아 추출물은 유기층 과수층으로 분획하여 실험에 사용하였으며, 연구 결과는 다음과 같다.

몰로키아 추출물 $\mathrm{A}$ 와 $\mathrm{B}$ 는 모두 포도상구균과 녹농균에 대해 항 균력이 있는 것으로 나타났다. 특히 추출물 $\mathrm{A}$ 는 포도상구균 보다 녹농균에 대해서, 추출물 $\mathrm{B}$ 는 녹농균보다 포도상구균에 대해서 유 의미한 효과가 있음을 관찰할 수 있었다.

몰로키아 추출물 A와 B의 Hs68 cell과 $\mathrm{HaCaT}$ cell에 대한 세포 독성 측정결과, 세포독성이 거의 없는 것으로 나타났다.

세포에 대한 산화스트레스 측정을 통해 항산화 능력을 조사하였 는데 추출물 $\mathrm{A}$ 와 B 모두 glutathione과 비교하여 유의미한 항산화 효과를 보이는 것으로 관찰되었다.

Western blotting과 Image J program을 통하여 몰로키아 추 출물의 콜라겐 합성 능력을 살펴본 결과, western blotting에서는 콜라겐의 합성이 유의하게 나타나지 않았으나 Image J program을 통해서는 합성 효과를 다소 관찰할 수 있었다.

본 연구를 통해서 몰로키아 추출물은 피부세포주인 Hs68 cell과 $\mathrm{HaCaT}$ cell에 대해 일정농도에서 안전한 생존율을 보이면서 주목 할만한 항산화 효과를 보였다. 또한, 포도상구균과 녹농균에 대해 서도 항균력이 관찰되어 피부 보호를 목적으로 하는 기능성 화장품 원료로서의 가능성을 확인할 수 있었다. 


\section{Acknowledgements}

이 연구는 한국 연구재단 이공학 개인기초연구지원사업( $(\mathrm{NRF}-$ 2016R1D1A1B03930171)의 연구비 지원으로 수행되었습니다.

\section{References}

Azuma K, Nakayama M, Koshioka M, Ippoushi K, Yamaguchi Y, Kohata K, Yamauchi Y, Ito H, Higashio H. Phenolic antioxidants from the leaves of Corchorus olitorius $\mathrm{L}$. Journal of Agricultural and Food Chemistry, 47: 39633966, 1999.

Cho M, Bae EK, Ha SD, Park J. Application of natural antimicrobials to food industry. Food Science and Industry, 38: 36-45, 2005.

Conner DE, Beuchat LR. Effects of essential oils from plants on growth of food spoilage yeasts. Journal of Food Science, 49: 429-434, 1984.

El-Mahdy AR, El-Sebaiy LA. Preliminary studies on the mucilages extracted from Okra fruits, Taro tubers, Jew's mellow leaves and Fenugreek seeds. Food Chemistry, 14: 237-249, 1984.

Farag RS, El-Khwas KH, Mohamed MS. Distribution of carotenoids in some fresh and boiled foods. Advances in Food Sciences, 20: 1-6, 1998.

Hampton MB, Orrenius S. Dual regulation of caspase activity by hydrogen peroxide: implications for apoptosis. Federation of European Biochemical Societies Letters, 414: 552-556, 1997.

Han JS, Yoo EH. Growth and development characteristics of Molokhia (Corchorus olitorius L.), a subtropical leafy vegetable. Horticultural Science \& Technology, 27: 49$54,2009$.

Han SH, Woo NRY, Lee SD, Kang MH. Antioxidaitve and antibacterial activities of endemic plants extracts in Korea. Korean Journal of Medicinal Crop Science, 14: 49-55, 2006.

Hong JK. A study on skin aging caused by free-radical and on efficacy of antioxidant vitamins. Asian Journal of Beauty and Cosmetology, 7: 51-62, 2009.

Jung CH, Choi IW, Kim HM, Seog HM. Physicochemical properties of mucilage from domestic Molokhia (Corchorus olitorius). Korean Journal of Food Science and Technology, 34: 757-761, 2002.
Kim HJ, Lee SG, Lee SP, Lee IS. Cholesterol improvement effects of fermented defatted soybean grits added to Corchorus olitorius. Korean Journal of Food Science and Technology, 43: 375-380, 2011.

Kim HS, Kim YH, Kim AJ. The manufacturing and biological activity evaluation of wheat and barley mixture bread prepared with Molokhia powder. The Korean Journal of Food and Nutrition, 28: 676-684, 2015.

Lee SN. The antioxidant effect of rutin in human dermal fibroblasts damaged by reactive oxygen species. Asian Journal of Beauty and Cosmetology, 12: 831-836, 2014.

Lee SY, Song EJ, Kim KBWR, Yoon SY, Kim SJ, Lee SJ, Hong YK, Lim SM, Ahn DH. Antimicrobial activity of ethanol extract from Sargassum thunbergii. Journal of the Korean Society of Food Science and Nutrition, 38: 502508, 2009

Lewis NG. Plant phenolics. In: Antioxidants in higher plants. Alscher RG, Hess JL (ed.), CRC Press, Boca Raton, pp135-169, 1993.

Marklund S, Marklund G. Involvement of the superoxide anion radical in the autoxidation of pyrogallol and a convenient assay for superoxide dismutase. European Journal of Biochemistry, 47: 469-474, 1974.

Oshodi AA. Comparison of proteins, minerals and vitamin C content of some dried leafy vegetables. Pakistan Journal of Scientific and Industrial Research, 35: 267-269, 1992.

Re R, Pellegrini N, Proteggente A, Pannala A, Yang M, RiceEvans C. Antioxidant activity applying an improved ABTS radical cation decolorization assay. Free Radical Biology and Medicine, 26: 1231-1237, 1999.

Uhm MJ, Kwon SW, Kim HJ, Song YJ. Influences of seeding dates and pinching height on tender shoot productivity of Moloheiya (Corchorus olitorius L.). Protected Horticulture and Plant Factory, 24: 196-201, 2015.

Voegeli R, Meier J, Doppler S, Sturzebecher J, Girard P. Elastase and tryptase determination on human skin surface: is enzymatic activity higher in UV-irritated and dry skin? Cosmetics and Toiletries, 111: 51-55, 1996.

Wayner DD, Burton GW, Ingold KU, Barclay LR, Locke SJ. The relative contributions of vitamin $\mathrm{E}$, urate, ascorbate and proteins to the total peroxyl radical-trapping antioxidant activity of human blood plasma. Biochimica et Biophysica Acta, 924: 408-419, 1987. 
Willcox JK, Ash SL, Catignani GL. Antioxidants and prevention of chronic disease. Critical Reviews in Food Science and Nutrition, 44: 275-295, 2004.

Yoshikawa M, Shimada H, Saka M, Yoshizumi S, Yamahara J, Matsuda H. Medicinal foodstuffs. V. Moroheiya. (1): absolute stereostructures of corchoionosides A, B, and $\mathrm{C}$, histamine release inhibitors from the leaves of Vietnamese Corchorus olitorius L. (Tiliaceae). Chemical and Pharmaceutical Bulletin, 45: 464-469, 1997.
Yu HE, Dela Paz LM, Bae YJ, Lee DH, Park JS, Kwak HS, Kim HK, Lee JS. Screening and extraction condition of antiaging bioactive substances from medicinal plants. Journal of the Korean Society of Food Science and Nutrition, 34: 1136-1142, 2005.

Zaika LL, Kissinger JC. Inhibitory and stimulatory effects of oregano on Lactobacillus plantarum and Pediococcus cerevisiae. Journal of Food Science, 46: 1205-1210, 1981. 


\section{국문초록}

\section{기능성 화장품 소재로서 몰로키아 추출물의 가능성}

김미정 ${ }^{1}$, 박세연 $2^{*}$

${ }^{1}$ 동덕여자대학교 보건향장학과, 서울, 한국

${ }^{2}$ 동덕여자대학교 응용화학과, 서울, 한국

목적: 본 연구는 몰로키아 추출물의 기능성 화장품 소재로서의 가능성을 확인하고자 진행하였다. 방법: 몰로키아 에탄올 추출물을 유기층과 수층으로 분획하여 추출물 A와 추출물 B를 얻었다. 항균 효과는 Staphylococcus aureus (S. aureus)와 Pseudomonas aeruginosa (P. aeruginosa)를 이용하여 몰로키아 추출물 A와 B의 $0.1,0.2 \mathrm{mg} / \mathrm{mL}$ 농도에서 측정하였다. 세포독성실험은 $\mathrm{Hs} 68$ cell 과 $\mathrm{HaCaT}$ cell에서 몰로키아 추출물 $\mathrm{A}$ 와 $\mathrm{B}$ 를 $10,20,40 \mu \mathrm{g} / \mathrm{mL}$ 의 농도로 처리하여 확인하였다. 항산화 효과는 형광 염료를 통해서 확 인하고 콜라겐 합성은 western blotting을 이용하여 분석하였다. 결과: 추출물 $\mathrm{A}$ 와 $\mathrm{B}$ 모두 두 균에 대해 농도의존적으로 항균 효과가 있음을 확인할 수 있었다. $\mathrm{Hs} 68$ cell과 $\mathrm{HaCaT}$ cell에 대한 세포독성은 크지 않은 것을 알 수 있었다. 추출물 $\mathrm{A}$ 와 B의 항산화 효과를 측정한 결과는 양성대조군인 glutathione에 비견할 수 있는 항산화력을 보였다. 마지막으로, 자외선에 의해 감소된 콜라겐이 몰로키아 추출물에 의해 미약하게 회복되는 것을 확인할 수 있었다. 결론: 연구를 통해 기능성 화장품의 소재로서 몰로키아 추출물의 가능성을 확인할수 있었다.

핵심어: 몰로키아, 세포독성, 항균 효과, 항산화 효과, 콜라겐 합성

이 연구는 한국 연구재단 이공학 개인기초연구지원사업(NRF-2016R1D1A1B03930171)의 연구비 지원으로 수행되었습니다.

\section{참고문헌}

김한수, 김영호, 김애정. 몰로키아 분말을 첨가한 밀·보리 혼합 식빵의 제조 및 생리활성 평가. 한국식품영양학회지, 28 : 676-684, 2015.

김현정, 이성규, 이삼빈, 이인선. 몰로키아 첨가 탈지대두grit (defatted soybean grit) 발효물의 콜레스테롤 개선 효과. 한국 식품과학회지, 43: 375-380, 2011.

엄미정, 권성환, 김희준, 송영주. 모로헤이야 파종시기와 적심높이에 따른 신초의 생산성 비교. 시설원예·식물공장, $24:$ 196-201, 2015.

유형은, Leaniza, 배영주, 이대형, 박종상, 곽한식, 김하근, 이종수. 각종 약용 식물로부터 노화 억제 관련 생리활성 물질의

탐색 및 추출 조건. 한국식품영양과학회지, 34: 1136-1142, 2005.

이성내. 활성산소종(Reactive Oxygen Species)으로 유도된 인간진피섬유아세포 손상에 대한 루틴(Rutin)의 항산화 효과. 아 시안뷰티화장품학술지, 12: 831-836, 2014.

이소영, 송유진, 김꽃봉우리, 윤소영, 김서진, 이소정, 홍용기, 임성미, 안동현. 지충이(Sargassum thunbergii) 에탄올 추출 물의 항균활성. 한국식품영양과학회지, 38: 502-508, 2009.

정창화, 최인욱, 김흥만, 석호문. 몰로키아(Corchorus olitorius) 잎에서 추출한 mucilage의 이화학적 특성. 한국식품과학회 지, 34: 757-761, 2002.

조미희, 배은경, 하상도, 박지용. 천연항균제의 식품산업에의 응용. 식품과학과 산업, 38: 36-45, 2005.

한승호, 우나리야, 이송득, 강명화. 국내 자생 식물 추출물의 항산화 활성 및 항균효과. 한국약용작물학회지, 14: 49-55, 2006. 한중술, 유은하. 아열대 엽채류 몰로키아의 생장과 발육 특성. 원예과학기술지, 27: 49-54, 2009.

홍재기. 활성산소에 의한 피부노화와 항산화비타민의 효능에 대한 이론적 고찰. 아시안뷰티화장품학술지, 7: 51-62, 2009. 


\section{中文摘要}

\section{长蒴黄麻（Molokhia）作为功效性化妆品原料的可行性研究}

金美貞 ${ }^{1}$, 朴世蓮 $^{2 *}$

${ }^{1}$ 同德女子大學保健香妝學科, 首尔, 韩国

2同德女子大學應用化學科，首尔，韩国

目的: 本研究旨在探讨长蒴黄麻（Molokhia）提取物作为功效性化妆品原料的可能性。方法: 将长蒴黄麻乙醇提取物分成 油层和水层，分别命名为提取物 $\mathrm{A}$ 和提取物 $\mathrm{B}$ 。利用金黄色葡萄球菌（Staphylococcus aureus, S. aureus）和铜绿假单胞菌

(Pseudomonas aeruginosa, P. aeruginosa) 研究浓度分别为 $0.1 、 0.2 \mathrm{mg} / \mathrm{mL}$ 的提取物A和提取物B的抗菌效果。在Hs68细 胞和HaCaT细胞中, 利用 3-(4,5-dimethylthiazol-2-yl)-5-(3-carboxymethoxyphenyl)-2-(4-sulfophenyl)-2H-tetrazolium, inner salt (MTS) 测定长蒴黄麻提取物A和提取物B的浓度分别为 $10 、 20 、 40 \mu \mathrm{g} / \mathrm{mL}$ 时的细胞毒性。利用苂光染料确定抗氧化作用, 并通 过使用western blotting分析胶原蛋白合成的效果。结果：长蒴黄麻提取物 $\mathrm{A}$ 和提取物 $\mathrm{B}$ 均显示对金黄色葡萄球菌和铜绿假单胞 菌具有浓度依赖性抗菌效果。长蒴黄麻提取物A和提取物B对Hs68和HaCaT细胞没有显示出细胞毒性。长蒴黄麻提取物 $A$ 和提 取物 $\mathrm{B}$ 的抗氧化效果与阳性对照群谷胱甘肽的抗氧化作用相当。最后, 长蒴黄麻提取物略微回复了由紫外线照射减少的胶原 蛋白。结论: 通过研究确认长蒴黄麻提取物作为功效性化妆品原料充分具有可行性。

关键词: 长蒴黄麻, 细胞毒性, 抗菌效果, 抗氧化效果, 胶原蛋白合成 